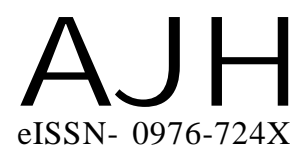

Received : 18.04.2014

Revised : 01.10.2014

Accepted : 17.10.2014

Members of the Research Forum

Associated Authors:

${ }^{1}$ Department of Floriculture and

Landscaping, Horticultural College

and Research Institute, Tamil Nadu

Agricultural University, COIMBATORE

(T.N.) INDIA

Author for correspondence

P. RANCHANA

Department of Floriculture and

Landscaping, Horticultural College

and Research Institute, Tamil Nadu

Agricultural University, COIMBATORE

(T.N.) INDIA

Email : ranchanahorti@gmail.com
THE ASIAN JOURNAL OF HORTICULTURE

Volume 9 | Issue 2 | Dec., 2014 |334-337

Visit us -www.researchjournal.co.in

RESEARCH PAPER

DOI : $10.15740 / \mathrm{HAS} / \mathrm{TAJH} / 9.2 / 334-337$

\title{
Methods for breaking dormancy and germination of tuberose (Polianthes tuberosa) seeds
}

\section{P. RANCHANA, M. KANNAN ${ }^{1}$ AND M. JAWAHARLAL ${ }^{1}$}

ABSTRACT : The seed germination study is the utmost important character to develop new hybrids after successful fruitset. But the seeds of tuberose did not show much response under favourable climatic condition. Hence, the aim of the study was to break the dormancy and increase its germination by using various chemicals viz., gibberellic acid, thiourea, potassium nitrate and indole butyric acid. Seed treatment with $\mathrm{GA}_{3} @ 250 \mathrm{ppm}$ for $8 \mathrm{hrs}$ was found to be effective in improving the germination by 12.50 per cent which was 63.68 per cent higher than control.

KEY WORDS : Tuberose, Seeds, Germination

HOW TO CITE THIS ARTICLE : Ranchana, P., Kannan, M. and Jawaharlal, M. (2014). Methods for breaking dormancy and germination of tuberose (Polianthes tuberosa) seeds. Asian J. Hort., 9(2) :334-337. 